\title{
Biohydrogen production gets airborne
}

The potential for developing commercially viable microbial $\mathrm{H}_{2}$ production systems as a renewable source of biofuel has been limited by the need for an anaerobic environment to enable photobiological $\mathrm{H}_{2}$ production in capable bacterial and algal species. Writing in Nature Communications, Bandyopadhyay et al. now show that the cyanobacterium Cyanothece sp. ATCC 51142 is capable of highly efficient $\mathrm{H}_{2}$ production under natural aerobic conditions.

The marine bacterium Cyanothece sp. ATCC 51142 has a diurnal metabolic cycle: photosynthesis and carbon fixation occur during daylight hours, and then at night high rates of respiration create a suboxic intracellular environment that enables $\mathrm{O}_{2}$-sensitive processes, including $\mathrm{N}_{2}$ fixation and $\mathrm{H}_{2}$ production. The authors developed a two-stage approach to monitor $\mathrm{H}_{2}$ production by Cyanothece sp. ATCC 51142. In the first stage, they grew the bacteria aerobically in an alternating 12-hour light-dark cycle. A second 'incubation' stage was then carried out, in which the authors

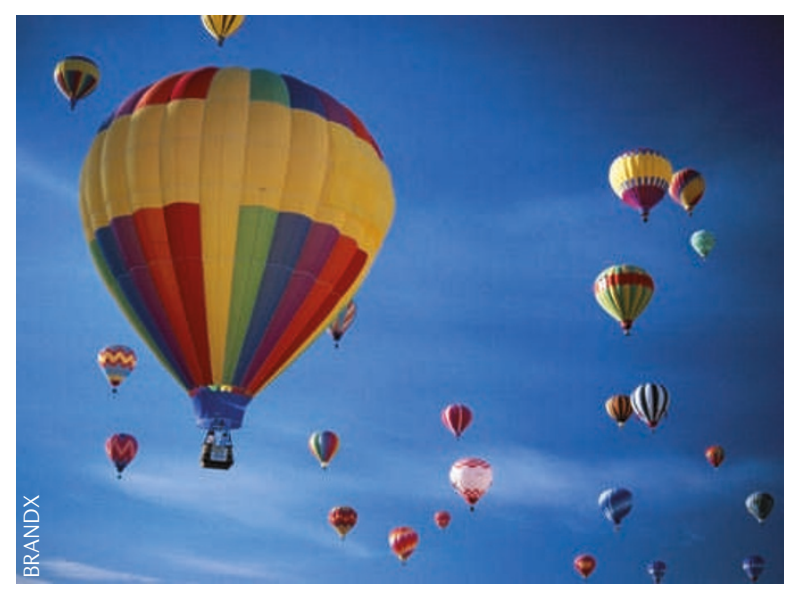

took cells from the end of a 12-hour light period and incubated them in air-tight vials for a further 12 hours under continuous illumination. Analysis of the head space at the top of the vial revealed high rates of $\mathrm{H}_{2}$ production $\left(>150 \mu \mathrm{mol} \mathrm{H}_{2}\right.$ per mg chlorophyll per hour) during this incubation period. Furthermore, the rate of $\mathrm{H}_{2}$ production could be enhanced by growing the cells with high levels of $\mathrm{CO}_{2}$ or glycerol.

The authors confirmed that $\mathrm{H}_{2}$ production was mediated by the nitrogenase system found in the bacterium. Interestingly, in the absence of molecular $\mathrm{N}_{2}$, nitrogenase systems channel all available electrons towards $\mathrm{H}_{2}$ production. Accordingly, when the authors incubated glycerolsupplemented Cyanothece sp. ATCC 51142 cells in the absence of $\mathrm{N}_{2}$, the rate of $\mathrm{H}_{2}$ production increased to up to $467 \mu \mathrm{mol} \mathrm{H}$ per $\mathrm{mg}$ chlorophyll per hour, which is an order of magnitude greater than the rates previously observed in other wild-type $\mathrm{H}_{2}$-producing model photosynthetic microorganisms under anaerobic conditions.

As glycerol and $\mathrm{CO}_{2}$ are both abundantly available as industrial waste products, the fact that they substantially enhance aerobic $\mathrm{H}_{2}$ production suggests that Cyanothece sp. ATCC 51142 is a potentially viable system for producing biohydrogen as a renewable fuel source.

Andrew Jermy

system

for producing

biohydrogen

as a renewable

fuel source.
ORIGINAL RESEARCH PAPER

Bandyopadhyay, A. et al. High rates of photobiological $\mathrm{H}_{2}$ production by a cyanobacterium under aerobic conditions. Nature Commun. 1, 139 (2010) 